\title{
INSECTS
}

\section{A NEW DRAGONFLY FOR MANITOBA - PRINCE BASKETTAIL}

Larry de March ${ }^{1}$, Peter Taylor ${ }^{2}$

1467 Churchill Drive, Winnipeg, MB, R3L 1W3, E-mail: <demarchl@mts.net>

2P.O. Box 597, Pinawa, MB, R0E 1L0, E-mail: <taylorp@granite.mb.ca>

This article documents two records, substantiated by photographs and specimens, of prince baskettail (Epitheca princeps), in extreme southeastern Manitoba. This dragonfly has an extensive range in eastern North America, with the northwestern range limit approaching the southeastern corner of Manitoba, but there are apparently no previous records for the province. ${ }^{1-3}$ Observations are described below, with further details in Table 1.

Seven Manitoba insect enthusiasts met at East Braintree (115 km ESE of Winnipeg) on 12 July 2009 to search for dragonflies and butterflies. At one stop along Provincial Road (PR) 308, about $12 \mathrm{~km}$ SSE of East Braintree (Table
1), P.T. noticed an unfamiliar dragonfly perched on a dead tamarack (Larix laricina) twig. The prominent spot pattern on the wings suggested female twelvespotted skimmer (Libellula pulchella) or common whitetail (Plathemis lydia), but L.d.M. identified it as a prince baskettail, based on the following features: relatively large size; long and slender abdomen held in an upcurved posture; colour pattern, especially the lack of stripes on the thorax. ${ }^{1,2,4}$ The dragonfly remained perched long enough to be photographed by several members of the group (Fig. 1 and front cover). The cerci and epiproct (abdominal appendages) indicated it was a male. It had brown eyes, a feature of immature males. As with other corduliid

Table 1. Coordinates of prince baskettail records for Manitoba and nearby areas of Minnesota and Ontario.

\begin{tabular}{|l|l|l|l|l|l|}
\hline Date & Observer(s) & Jurisdiction & $\begin{array}{l}\text { Latitude } \\
\left({ }^{\circ} \mathrm{N}\right)\end{array}$ & $\begin{array}{l}\text { Longitude } \\
\left({ }^{\circ} \mathrm{W}\right)\end{array}$ & Comments \\
\hline $\begin{array}{l}10 \text { July } \\
2004\end{array}$ & L. Barber & Manitoba & 49.73 & 95.18 & $\begin{array}{l}\text { Lyons Lake; see } \\
\text { text }\end{array}$ \\
\hline $\begin{array}{l}\text { 12 July } \\
2009\end{array}$ & $\begin{array}{l}\text { P. Taylor, L. de } \\
\text { March et al. }\end{array}$ & Manitoba & 49.5210 & 95.5617 & $\begin{array}{l}\text { MB P.R. 308; see } \\
\text { text }\end{array}$ \\
\hline Unknown & Unknown & $\begin{array}{l}\text { Minnesota } \\
\text { (Beltrami } \\
\text { County) }\end{array}$ & $\begin{array}{l}\text { Approx. } \\
48.0\end{array}$ & $\begin{array}{l}\text { Approx. } \\
94.9\end{array}$ & Ref. 5 \\
\hline $\begin{array}{l}\text { 4 June } \\
\text { 1999 }\end{array}$ & $\begin{array}{l}\text { H. Davies, J.M. } \\
\text { Duncan }\end{array}$ & $\begin{array}{l}\text { Ontario } \\
\text { (Kenora } \\
\text { District) }\end{array}$ & 49.7005 & 94.3604 & $\begin{array}{l}\text { C.D. Jones; Ref. 6; } \\
\text { Canadian National } \\
\text { Collection of Insects }\end{array}$ \\
\hline
\end{tabular}




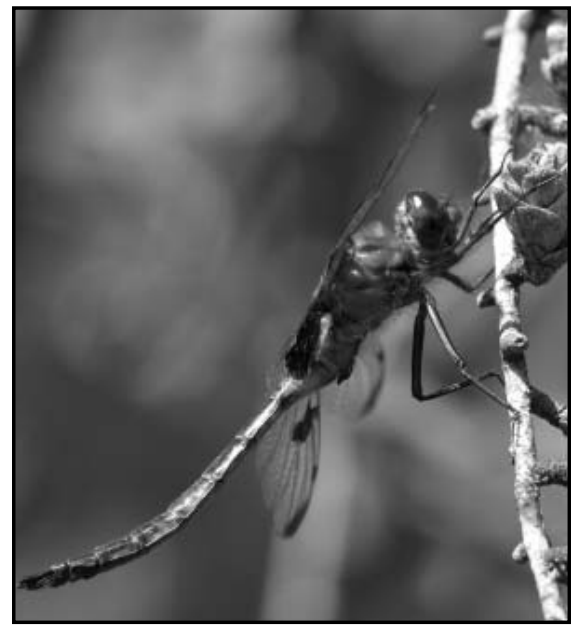

Figure 1. Prince baskettail near Manitoba Provincial Road 308, 12 July 2009 (lateral view).

Larry de March

dragonflies (emeralds), male prince baskettails' eyes turn green at sexual maturity.

This proved to be the second record of prince baskettail in Manitoba, the first being a confirmed breeding record very close to the provincial boundary. Lance Barber had collected two females (one found dead), six exuviae (empty larval cases; Fig. 2), and one dead larva on 10 July 2004 at Lyons Lake, which is on the Trans-Canada Highway $1.5 \mathrm{~km}$ W of the Manitoba-Ontario boundary and about $36 \mathrm{~km} \mathrm{NE}$ of the PR 308 locality (M. Hughes, pers. comm.). Hughes confirmed the identities of all specimens, which are preserved in the Manitoba Conservation Data Centre collection.

Habitat for the prince baskettail can be "moderate-sized streams to fair-sized rivers, usually slow-flowing, and large ponds and lakes... more at lakes in northern part of range". ${ }^{1}$ Lyons Lake is a typical, small shield lake surrounded by mixed forest. The habitat along PR 308 was low-lying, open-canopy forest, primarily black spruce (Picea mariana) and tamarack, with a well-filled drainage channel and many drowned trees on one side (Fig. 3). The nearest potential larval habitat appeared to be the channel, and

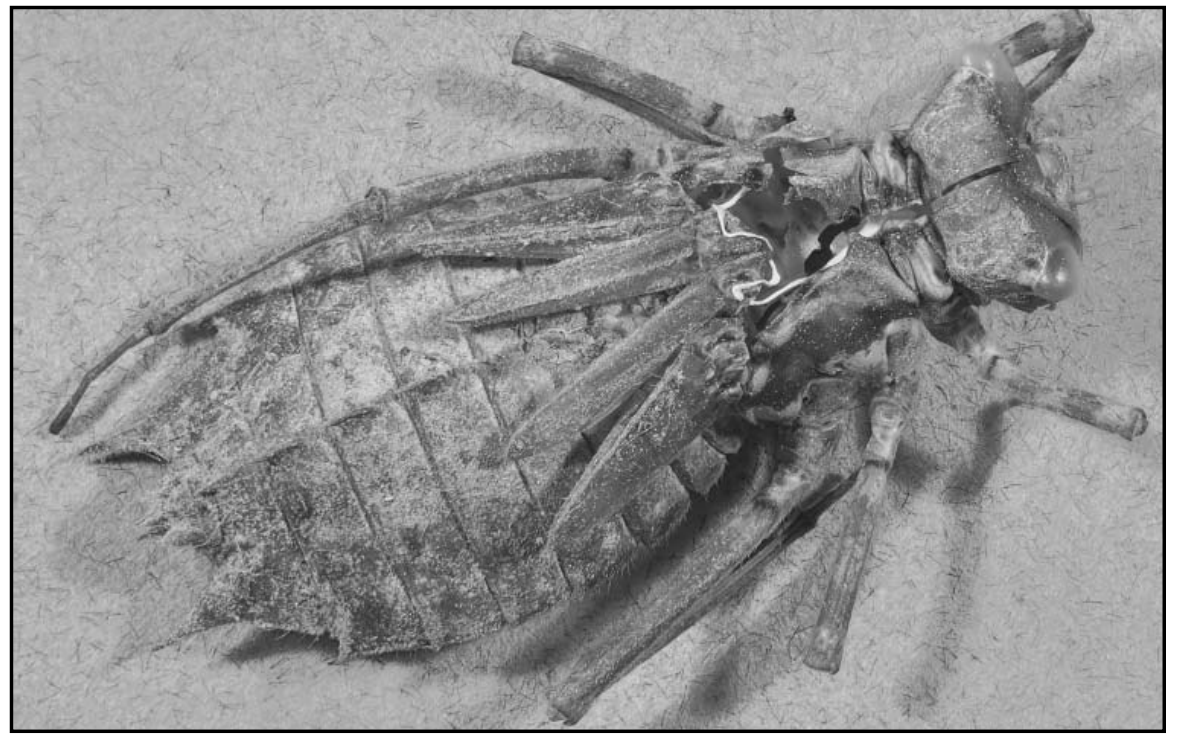

Figure 2. Prince baskettail exuvia collected at Lyons Lake, MB, on 10 July 2004.

Larry de March 


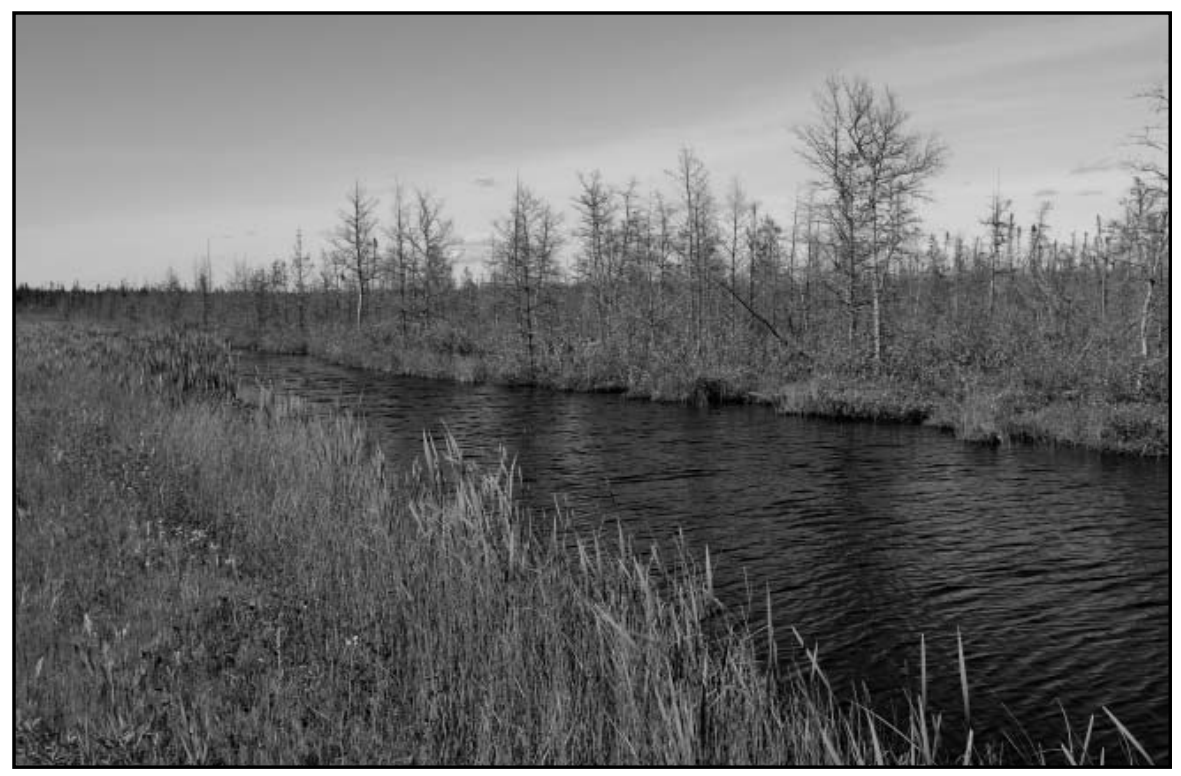

Figure 3. Drainage channel and forest habitat at prince baskettail locality near Manitoba Provincial Road 308, 12 July 2009.

Larry de March

the nearest larger water body is Birch Lake, $2 \mathrm{~km}$ to the NW.

The two nearest previous records to Manitoba are in Beltrami County, Minnesota, and near the north shore of Lake of the Woods east of Kenora, Ontario (Table 1). These are respectively about $174 \mathrm{~km} \mathrm{~S}$ and $89 \mathrm{~km} \mathrm{E}$ by ENE of the PR 308 locality. 5,6 There is a cluster of records farther SE of Kenora in the Rainy River district of Ontario. ${ }^{6}$ The Manitoba records, though adding to the provincial list, represent only a modest range extension. Given the limited exploration of this region by naturalists, local populations could be long-standing and may not necessarily represent active range expansion. This is one of several dragonfly species that reach their northwestern range limits in or near extreme southeastern Manitoba; the region merits further exploration.

\section{Acknowledgements}

We thank John Abbott, Nick Donnelly, Marjorie Hughes, Colin Jones, Kurt Mead,
Dennis Paulson, Richard Rowe, and Dianne Rowse for helpful correspondence. Co-observers on the 12 July 2009 outing were Alfred Aug, Deanna Dodgson, Lorne Klassen, Nella Schmidt, and Reto Zach.

1. Paulson D (2009) Dragonflies and Damselflies of the West. Princeton University Press, Princeton, NJ.

2. Mead K (2009) Dragonflies of the North Woods (2 ${ }^{\text {nd }}$ edn). Kollath and Stensaas Publishing, Duluth, MN.

3. Hughes ML, Duncan JR (2003) The dragonflies of Manitoba: an updated species list. Blue Jay 61:168-175.

4. Jones CD, Burke C (2001) Identification pitfalls: separating female twelve-spotted skimmer from female common whitetail. Ontario Insects 7(1):57. (Available at http://www.ontarioinsects.org/ publications.htm)

5. Hamrum CL, Anderson MA, Boole M (1971) Distribution and habitat preference of Minnesota dragonfly species (Odonata, Anisoptera) II. Journal of the Minnesota Academy of Science 37:93-96.

6. Ontario Ministry of Natural Resources, Ontario Odonata Atlas. (Available at http://nhic.mnr.gov. on.ca/MNR/nhic/odonates/atlas.html) 